\title{
Anti-Adenylate Kinase 5 Encephalitis With Histologic Evidence of CNS Vasculitis
}

Alex Vicino, MD, Valentin Loser, MD, Paolo Salvioni Chiabotti, MD, Jean Philippe Brouland, MD, and Renaud Du Pasquier, MD

Neurol Neuroimmunol Neuroinflamm 2021;8:e1010. doi:10.1212/NXI.0000000000001010

Encephalitis with antibodies against intracellular antigen adenylate kinase 5 (AK5) is a recently discovered entity; only 16 cases with characteristic clinical, radiologic, and CSF presentation have been described..$^{1-3}$ There is no report of histologic association with vasculitis.

We present a case of AK5 limbic encephalitis with histologic evidence of CNS vasculitis.

\section{Case}

A 58-year-old woman was admitted for investigation of headaches, memory impairment, behavioral changes, and sleep disturbances, progressing over approximately 1 month and impairing her daily activities.

Neuropsychologic examination showed a multimodal disorientation, severe executive and attentional deficits, disinhibition, and severe anterograde memory impairment affecting encoding, ideomotor apraxia, and left multimodal neglect. The rest of the neurologic and general examinations were normal.

Basic laboratory tests were normal. A brain MRI at admission (1 month after symptoms onset) showed bilateral, right predominant, mesiotemporal $\mathrm{T} 2$-fluid-attenuated inversion recovery (FLAIR) hyperintensity with gadolinium enhancement (figure). CSF analysis showed lymphocytic pleocytosis (120 cells $/ \mathrm{mm}^{3}, 98 \%$ lymphocytes), hyperproteinorachia $(1,032 \mathrm{mg} / \mathrm{L})$, intrathecal IgG synthesis, and normal glucose and lactate levels. PCR for encephalitis, including HSV-1, was negative. Tuberculosis and Whipple disease were ruled out. Immunologic studies, CSF cytology, and flow cytometry were unremarkable.

A whole-body CT scan showed some pulmonary parenchymal nodules, known since 2012 and remaining unchanged. In addition, whole-body 18F-FDG PET showed a hypermetabolic cervical lymph node, without histologic abnormalities on biopsy. EEG was normal. The antineural antibody panel in the serum and CSF was negative. However, the tissue-based assay of serum and CSF showed a cytoplasmic fluorescence in hippocampal, cerebellar, and brain stem neurons. Further novel antibody testing in the IDIBAPS laboratory (Prof Dalmau), Barcelona, demonstrated the presence of AK5 antibodies in the serum and CSF.

We discontinued antiviral and antibiotic treatment after the negative infectious workup and introduced a course of IV methylprednisolone $(1 \mathrm{~g} / \mathrm{d})$ for 5 days.

The clinical course was unfavorable, with persistence of cognitive disorders and appearance of mood swings, depression, and severe anxiety. A repeat MRI at 1 month showed stronger
Correspondence

Dr. Vicino

alex.vicino@chuv.ch 

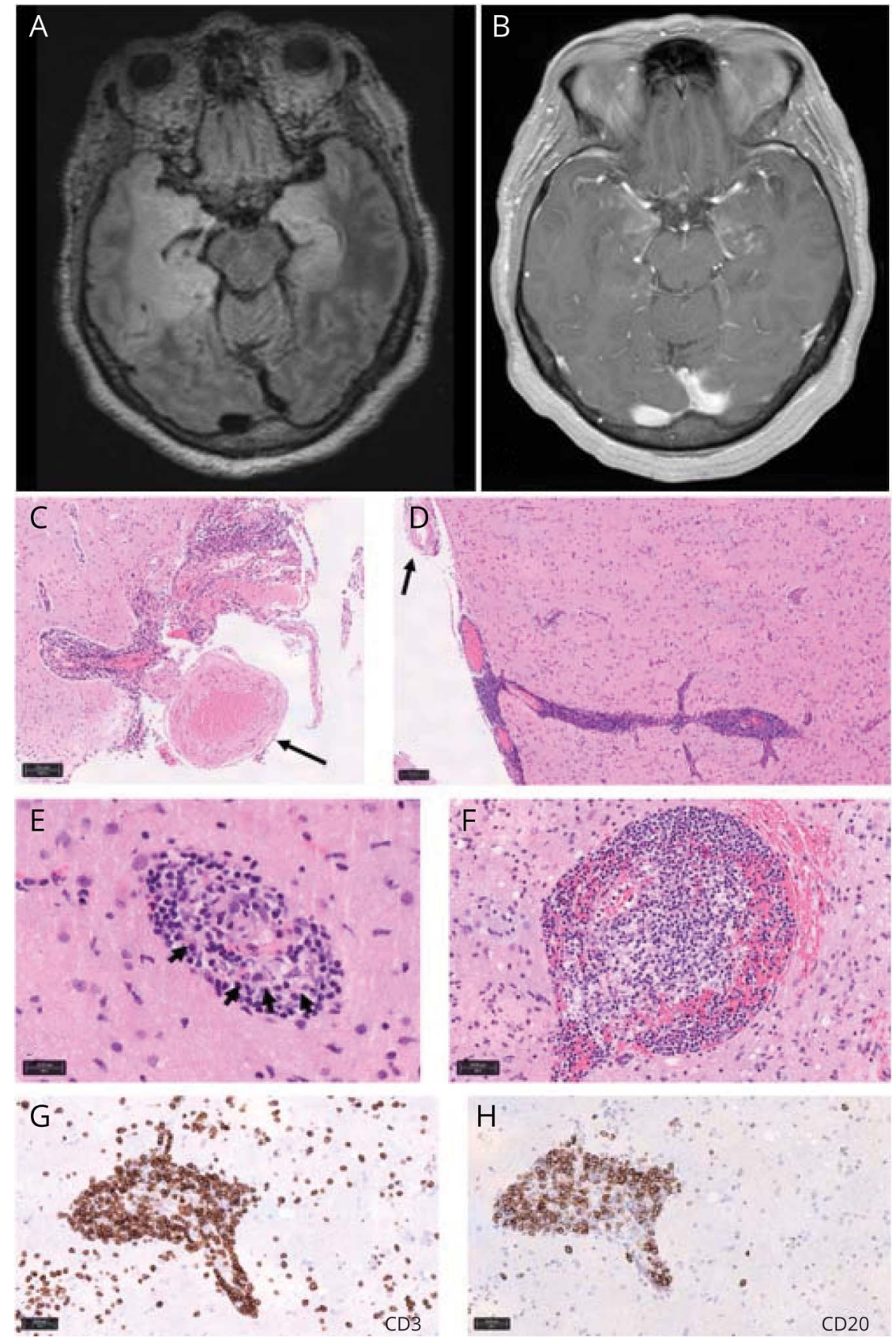

Initial MRI with mesiotemporal T2/FLAIR hypersignal (A) and gadolinium enhancement (B). Brain biopsy shows an infiltration of the meningeal and intraparenchymatous blood vessels ( $C$ and $D)$ that spares the larger meningeal arteries (arrows); perivascular infiltrate is, in places, important and extends into the vascular walls (E and $F$ ) resulting in vascular wall lesions such as a fragmentation of elastic fibers ( $E$, arrows), extravasation of red blood cells (F), and occlusion of vascular lumen. There is no obvious deposition of fibrin or thrombus; the lymphocyte infiltrate of vascular wall is composed of small T-cell $\mathrm{CD}^{+}(\mathrm{G})$ and rarer small B-cell $\mathrm{CD}^{+} \mathrm{O}^{+}(\mathrm{H})$ without abnormal large $\mathrm{B}$ cell. Brain parenchyma is punctuated by T-cell lymphocytes and very rare B cells without obvious perineuronal disposition (C-F: hematoxylin-eosin and $\mathrm{G}$ and $\mathrm{H}$ : avidin-biotin complex-peroxidase/ 3,3'-diaminobenzidine). Scale and magnification: $\mathrm{C}-115.5 \mu \mathrm{m}, 9 \times$; D-102.4 $\mu \mathrm{m}, 10 x ; \mathrm{E}-25.03 \mu \mathrm{m}$, 40x; F- 50.05 $\mu \mathrm{m}$ and 20x; G-50.05 $\mu \mathrm{m}, 20 x ;$ and $\mathrm{H}-50.05 \mu \mathrm{m}, 20 \times$
T2-FLAIR hypersignals in both temporal lobes, whereas a brain 18F-FET PET excluded a glioma. A first stereotactic biopsy of the right temporal lobe, performed 3 weeks after the methylprednisolone course, was not conclusive.

However, a second brain biopsy (figure) showed vascular lesions affecting the meningeal and intraparenchymal smallsized blood vessels, sparing the larger meningeal arteries (figure). A stratified perivascular infiltration of mononuclear cells of varying importance and segmental distribution was observed in the vessel. The infiltrate consisted of small $\mathrm{T}$ cells (predominantly expressing CD3, CD5, and CD4) and rarer
B lymphocytes $\left(\mathrm{CD} 20^{+}\right)$and histiocytes $\left(\mathrm{CD} 68^{+}\right)$, without polymorphonuclear or giant cells. The infiltrate sometimes extended to the entire vascular wall with partial or total involvement of the blood vessel circumference. In the most affected vessels, mainly of small caliber, there were signs of vessel wall lesions with rupture of the elastic fibers and an inflammatory infiltrate that compressed the vascular lumen causing narrowing or total occlusion, but without obvious thrombi, necrosis, or fibrin deposits. There were also areas of perivascular hemorrhagic flooding, indicating a vascular leakage. The surrounding parenchyma displayed reactive changes such as extensive neuronal loss, vacuolization, signs 
of demyelination, astrogliosis, and a slight, diffuse lymphocytic $\mathrm{T}$ infiltrate, without perineuronal grouping, reflecting ischemic or subischemic phenomena probably related to the vascular lesions.

These aspects, in the absence of other causes, and notably of amyloid deposits, infectious agents, and atypical lymphocytes (which might have suggested a lymphoma), were initially consistent with the exclusion diagnosis of primary vasculitis of the CNS.

However, with the clinical and radiologic setting typical of autoimmune limbic encephalitis and the presence of anti-AK5 antibodies, we considered the autoimmune encephalitis and small vessel vasculitis to be the expression of a single process. We retained, therefore, the diagnosis of CNS vasculitis secondary to AK5 autoimmune limbic encephalitis. The patient was started on immunotherapy with oral prednisone $(1 \mathrm{mg} /$ $\mathrm{kg} / \mathrm{d}$ ) and IV pulse cyclophosphamide (1 dose every 2 weeks for a month and followed by 1 dose every 3 weeks, 4 times).

Neuropsychologic examination 6 weeks after discharge found a normalization of orientation and gradual improvement of executive, mnesic, and attentional functions.

\section{Discussion}

We report a case of limbic encephalitis with the presence of anti-AK5 antibodies and a brain biopsy showing signs of vasculitis. To our knowledge, this is the first report on vasculitis associated with antineural antibodies, and especially anti-AK5.

In autoimmune encephalitis caused by intracellular antibodies (typically anti-Hu limbic encephalitis), histopathologic studies usually show extensive parenchymal inflammatory infiltrates, mainly $\mathrm{CD}^{+}$lymphocytes, and a significant neuronal loss. ${ }^{4}$ The only autopsy of a patient with AK5 encephalitis showed extensive loss of neurons, microgliosis, astrogliosis, and perivascular and parenchymal infiltration of $\mathrm{T}$ lymphocytes, mainly $\mathrm{CD} 8+.^{5}$ In our patient, the brain biopsy showed evidence of CNS vasculitis with transmural $\mathrm{T}$-cell infiltrates.
This novel description of AK5-related vasculitis may bring new insights into the physiopathology of autoimmune encephalitis related to antineuronal antibodies. Indeed, some degree of vasculitis may contribute more often than previously believed to the neurologic deficits and the mechanism may go unrecognized because of the rarity of cerebral biopsy. Alternatively, vasculitis could be a feature restricted to antiAK5 antibodies entity.

It is worth noting that the outcome of the patient was favorable, and we believe that the aggressive cyclophosphamide treatment was instrumental. Indeed, the fact that AK5 is an intracellular antigen and the presence of vasculitis are both elements pleading for a treatment targeting cellmediated rather than humoral-mediated immunity, such as rituximab.

\section{Acknowledgment}

The authors thank Melanie Price-Hirt, $\mathrm{PhD}$, for English language correction and editing.

\section{Study Funding}

The authors report no targeted funding.

\section{Disclosure}

The authors report nothing to disclose relevant to the manuscript. Go to Neurology.org/NN for full disclosures.

\section{Publication History}

Received by Neurology: Neuroimmunology \& Neuroinflammation December 31, 2020. Accepted in final form March 10, 2021.

\section{References}

1. Do LD, Chanson E, Desestret V, et al. Characteristics in limbic encephalitis with antiadenylate kinase 5 autoantibodies. Neurology. 2017;88(6):514-524.

2. Tuzun E, Rossi JE, Karner SF, Centurion AF, Dalmau J. Adenylate kinase 5 autoimmunity in treatment refractory limbic encephalitis. J Neuroimmunol. 2007; 186(1-2):177-180.

3. Bien CI, Nehls F, Kollmar R, et al. Identification of adenylate kinase 5 antibodies during routine diagnostics in a tissue-based assay: three new cases and a review of the literature. J Neuroimmunol. 2019;334:576975.

4. Dalmau J, Graus F. Antibody-mediated encephalitis. N Engl J Med. 2018;378(9): 840-851.

5. Ng AS, Kramer J, Centurion A, et al. Clinico-pathological correlation in adenylate kinase 5 autoimmune limbic encephalitis. J Neuroimmunol. 2015;287:31-35. 


\title{
Neurology \\ Neuroimmunology \& Neuroinflammation
}

\author{
Anti-Adenylate Kinase 5 Encephalitis With Histologic Evidence of CNS Vasculitis \\ Alex Vicino, Valentin Loser, Paolo Salvioni Chiabotti, et al. \\ Neurol Neuroimmunol Neuroinflamm 2021;8; \\ DOI 10.1212/NXI.0000000000001010
}

This information is current as of May 11, 2021

\section{Updated Information \& Services}

References

Subspecialty Collections

Permissions \& Licensing

Reprints including high resolution figures, can be found at: http://nn.neurology.org/content/8/4/e1010.full.html

This article cites 5 articles, 0 of which you can access for free at: http://nn.neurology.org/content/8/4/e1010.full.html\#\#ref-list-1

This article, along with others on similar topics, appears in the following collection(s):

All Clinical Neurology

http://nn.neurology.org//cgi/collection/all_clinical_neurology

Autoimmune diseases

http://nn.neurology.org//cgi/collection/autoimmune_diseases

Vasculitis

http://nn.neurology.org//cgi/collection/vasculitis

Information about reproducing this article in parts (figures,tables) or in its entirety can be found online at:

http://nn.neurology.org/misc/about.xhtml\#permissions

Information about ordering reprints can be found online:

http://nn.neurology.org/misc/addir.xhtml\#reprintsus

Neurol Neuroimmunol Neuroinflamm is an official journal of the American Academy of Neurology.

Published since April 2014, it is an open-access, online-only, continuous publication journal. Copyright

Copyright $\odot 2021$ The Author(s). Published by Wolters Kluwer Health, Inc. on behalf of the American

Academy of Neurology.. All rights reserved. Online ISSN: 2332-7812.

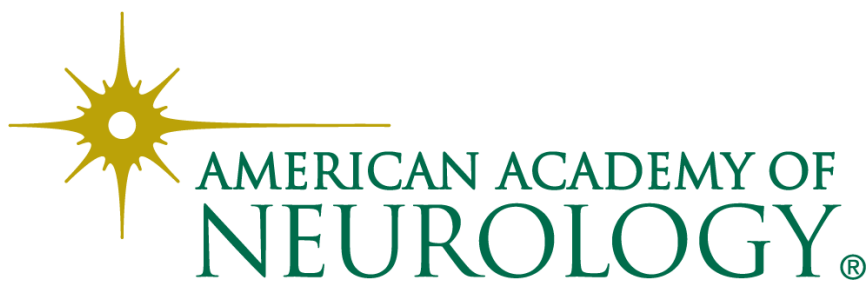

